\title{
Anne Sütü ve COVİD-19
}

\section{Breast Milk and COVID-19}

\section{Vildan Oğuz ${ }^{1}$, Çiğdem Bozkır²}

Geliş tarihi/Received: 20.05.2021 • Kabul tarihi/Accepted: 20.08.2021

\section{ÖZET}

Yeni tip koronavirüs hastalığı (COVID-19), Aralık 2019'da Wuhan'da ortaya çıkmıştır. Kısa bir süre sonra pandemi haline gelen bu hastalık milyonlarca insanın enfekte olmasına ve ölümüne sebep olmuştur. Solunum damlacıkları yoluyla bulaşan CoviD-19'dan korunmada maske gibi kişisel koruyucu ekipmanlar kullanmanın ve özellikle el hijyenine dikkat etmenin etkili olduğu bildirilmektedir. Hastalık açısından gebelik ve yenidoğan dönemi riskli kabul edilmektedir. CoviD-19'la ilgili olarak anne-yenidoğan ilişkisi üzerine yapılan araştırmalarda emzirme sırasındaki temasın bulaş için risk oluşturmadığı ve enfekte annelerin gerekli koruyucu ekipmanları kullanarak emzirmeyi sürdürmeleri gerektiği sonucuna varılmıştır. Özellikle yaşamının ilk günlerinde anne sütü almayan yenidoğanlarda farklı sağllk sorunları gözlenmektedir. Enfekte annelerin sütü ile yapılan birçok çalışmada, anne sütünde virüs tespiti yapılmamıştır. Aksine antikor testlerinde çeşitli bağışıklık sağlayan antikorlara rastlanmıştır. Dünya Sağlık Örgütü (DSÖ) annelerin gerekli tedbirler alarak ve hijyen kurallarına uyarak emzirmeye devam etmesini, temasın mümkün olmadığı zorunlu durumlarda ise süt pompaları ile sütün sağılarak çocuğun anne sütü ile beslenmesinin sağlamasını önermektedir.

Anahtar kelimeler: COVID-19, koronavirüs, anne sütü, emzirme

\begin{abstract}
The new coronavirus disease (COVID-19) emerged in Wuhan in December 2019. This disease, which became a pandemic after a short time, caused the infection and death of millions of people. It is reported that using personal protective equipment such as a mask and paying attention to hand hygiene is effective in protecting against COVID-19 transmitted by respiratory droplets. The pregnancy and neonatal period are considered risky in terms of the disease. In the studies on the mothernewborn relationships regarding COVID-19, it was concluded that contact during breastfeeding does not pose a risk for contamination and infected mothers should continue breastfeeding using necessary protective equipment. Different health problems can be seen in newborns who do not receive breast milk, especially in the first days of life. Many studies conducted with the milk of infected mothers did not detect viruses in breast milk. On the contrary, various immunogenic antibodies were found in antibody tests. The World Health Organization (WHO) recommends that mothers continue to breastfeed by taking necessary precautions and complying with hygiene rules, and ensure that the child is breastfed by expressing milk with milk pumps in cases where contact is not possible.
\end{abstract}

Keywords: COVID-19, coronavirus, breast milk, breastfeeding

1. İletişim/Correspondence: Tekirdağ Namık Kemal Üniversitesi, Sağllk Yüksekokulu, Beslenme ve Diyetetik Bölümü, Tekirdağ, Türkiye

E-posta: vildan_oguz23@hotmail.com • 『 https://orcid.org/0000-0002-5443-888X
2. İnönü Üniversitesi, Sağlık Bilimleri Fakültesi, Beslenme ve Diyetetik Bölümü, Malatya, Türkiye • ๑ https://orcid.org/0000-0002-1103-6290 


\section{GíRIŞ}

Şiddetli akut solunum yolu sendromu yeni koronavirüs (SARS-CoV-2), ilk olarak 2019 yll Aralık ayında Çin'in Wuhan şehrinde insandan insana solunum damlacıkları yoluyla bulaşması ile tanımlanmıştır (1). Öksürük, ateş, nefes darlığı ve eklem ağrıları en yaygın görülen belirtileridir (2). Dünya Sağllk Örgütü (DSÖ) 11 Mart 2020'de küresel yayılım gösteren hastalığı pandemi olarak kabul ettiğini bildirmiştir (3).

Salgının başlarında sınırlı kaynaklar sebebi ile gebe kadınlara ve yenidoğana ilişkin bulaş riski belirsiz olsa da (4) salginin ilerlemesiyle her 8 gebe kadından birinin COViD-19 testinin pozitif çıktığ bildirilmiştir (5).

Anne sütü; yenidoğanda optimal büyüme ve gelişme için gerekli olan tüm sıvı, enerji ve besin ögelerini içeren, biyoyararlılı̆̆ı yüksek, sindirimi kolay, doğal bir besindir. Anne sütü ile beslenmenin hem bebek, hem de anne için gelişimsel, psikolojik, sosyal, ekonomik ve bağışıklık sistemini güçlendirici faydaları gibi birçok yönden olumlu etkileri bulunmaktadır (6).

$\mathrm{Bu}$ çalışmada, son bir yll içerisinde CoviD-19 bulaşında anne sütünün koruyuculuğu, emzirme ile bulaş riski, anne sütünden virüs ya da antikor geçişi konularında yapılan araştırmaların ve bu durumların doğurduğu sonuçlar için geliştirilen önerilerin derlenmesi amaçlanmıştır.

\section{Covì-19}

Çin'in Wuhan kentinde 2019 yllının sonunda SARS-CoV-2 virüsünün neden olduğu hastalıktır. Hızlı bir şekilde pandemiye dönüşen bu hastalık küresel düzeyde ciddi bir sorun haline gelmiştir (7). COVID-19, hasta kişilerin öksürme veya hapşırma yolu ile yüzeylere saçtığı ya da havada asılı kalan damlacıkların mukozaya temas etmesiyle bulaşmaktadır (7). Koronavirüsün inkübasyon süresinin 14 gün olduğu belirlenmiş, fakat çoğu vakada 4-5 gün sonrasında inkübasyon gerçekleşmiştir (8).
Mevcut verilere göre bu sürenin 2-14 gün olarak kabul edildiği bildirilmiştir (2).

Koronavirüsün en sık görülen semptomlarının ateş, öksürük, yorgunluk, baş ağrısı, ishal ve nefes darlığı olduğu belirlenmiştir (9). Kardiyovasküler hastalık, akciğer ve böbrek hastalı̆̆l, diyabet, hipertansiyon, kanser gibi kronik hastalığı olanlar ve yaşlılarda semptomlar daha ağır seyretmektedir (10).

Hastalığın teşhisi, solunum yollarından alınan sürüntü örneklerinin Polymerase Chain Reaction (PCR) testi ile yapılmaktadır (11). Hastalıktan korunmak için insan temasının azaltılması, şüpheli vakaların izolasyonu ve maske gibi kişisel koruyucu ekipmanların kullanılması önerilmektedir (2).

\section{CovīD-19 ve Bağışıklık}

Bağışılklık (immünite), konağın hastalığa neden olan organizmalara karşı savunulması olarak tanımlanmaktadır. Konağın savunmasını sağlayan hücreler ve dokuların toplamı immün sistemi ifade etmektedir. İmmün sistemin en önemli işlevi, enfeksiyonların oluşumunu önlemek veya oluşan enfeksiyonu iyileştirmektir (12).

Bağışıklık sisteminin işleyişinde beslenme durumu önemli bir rol oynamaktadır. Beslenme durumunun bağışıklık sistemine etkisi özellikle yaşamın ilk iki yllında anne sütü ile oldukça ilişkilidir. Anne sütü ile beslenme, yaşamın ilk yıllarında immün sistemi destekleyen ve gelişimini sağlayan biyoaktif bileşenleri içermektedir (14). İmmün sistem gelişimi, yaşamın ilerleyen yıllarında da etkili olmakla birlikte yaşllığga bağlı azalan besinögesi alımıla malnütrisyon gelişime riski bağışıklık sistemi desteğinin azalmasına neden olmaktadir (13).

\section{Anne Sütü ve Önemi}

Anne sütü; hem besleyici hem de biyoaktif bileşenler açısından bileşiminde değişiklik gösteren, kişiye özel bir besindir. Anne sütünün bileşiminin dinamik 
olması yenidoğanın yeterli ve dengeli beslenmesi ile bağışıklık sisteminin gelişiminin tamamlanmasını sağlar.Buözellikleriileyenidoğaniçinözellikle bulaşıcı hastalıklara karşı koruma sağlarken yetişkinlik döneminde görülebilecek kronik hastalıkların riskini de düşürmektedir. Anne sütü ile beslenmenin, sadece bebekler için değil aynı zamanda anne için de sağlık, sosyal ve ekonomik yararlar gibi çok yönlü olumlu etkileri bulunmaktadır $(6,14)$.

Dünya Sağlık Örgütü (DSÖ) ve Birleşmiş Milletler Çocuklara Yardım Fonu (UNICEF) uluslararası düzeyde 1992 yllında "Bebek Dostu Hastane" uygulamasını hayata geçirmiş ve anne sütü ile beslenmenin arttırılması için özellikle gelişmekte olan ülkelerde pratik uygulamalar gerçekleşmiştir. $\mathrm{Bu}$ yaklaşım birçok ülkede anne sütü ile beslenme oranının arttırılmasına yönelik hastane uygulamalarında gözle görünür değişikliklere olanak tanımıştır (15). Dünya Sağlık Örgütü; ilk 6 ay sadece anne sütü kullanımını, 6. aydan itibaren ek besinler ile birlikte iki yaş ve üzerinde emzirmenin sürdürülmesini önermektedir (16).

Anne sütünün besin değeri: Anne sütü bileşenleri, salgılandığı döneme ve emzirme süresine göre değişiklik gösterir. Doğumdan sonra ilk 4-5 günde salgılanan süte kolostrum denir. Kolostrum bebekteki mekonyumun çıkışını kolaylaştırmaktadır. Kolostrum içerdiği besin ögelerinden çok yaşamın ilk zamanlarında sağlığı koruyucu etkisi ve gastrointestinal fonksiyonların düzenlenmesi açısından önemlidir (6). Kolostrum doğumdan 5-10 gün sonra geçiş sütü özelliğini alır. Üçüncü haftadan itibaren ise olgun süt salgılanmaya başlar. Tablo 1'de görüldüğü gibi kolostrumun olgun süte göre protein içeriği yüksek, yağ ve laktoz içeriği ise düşüktür (17).

Anne sütündeki protein içeriği inek sütünden daha düşük olmasına rağmen, tek başına bebeğin yaşamının ilk altı ayında protein gereksinimini karşılayacak kadar yüksek biyoyararlılığa sahiptir (18). Bunun sebebi anne sütündeki kazein/whey proteinlerinin 40/60 oranında bulunmasıdır (6).
Tablo 1. Kolostrumun ve olgun anne sütünün besin ögesi içeriği

\begin{tabular}{lcc}
\hline & $\begin{array}{c}\text { Kolostrum } \\
(\mathbf{1 0 0} \mathbf{~} \mathbf{L})\end{array}$ & $\begin{array}{c}\text { Olgun Anne Sütü } \\
\mathbf{( 1 0 0 ~} \mathbf{~ L )})\end{array}$ \\
\hline Enerji (kkal) & 58 & 70 \\
Protein (g) & 2.3 & 0.9 \\
Lipit (g) & 1.8 & 3.4 \\
Laktoz (kkal) & 5.6 & 6.3 \\
Kazein (mg) & 140 & 187 \\
Laktoferrin (mg) & 330 & 167 \\
Nitrojen (mg) & 360 & 171 \\
A vitamini (mcg) & 89 & 67 \\
E vitamini (mcg) & 1280 & 315 \\
K vitamini (mcg) & 0.23 & 0.21 \\
Sodyum (mg) & 48 & 18 \\
Demir (mcg) & 45 & 40 \\
\hline
\end{tabular}

Anne sütündeki yağların \%98’i trigliseritlerden oluşmaktadır. Emzirmenin son döneminde yağ oranı emzirmenin başlangıcına göre daha yüksektir. $\mathrm{Bu}$ durum bebekte doygunluk hissi oluştuğunda emzirmeyi bırakması sağlayarak oluşabilecek obezite riskinden korunması için önemli bir etken olarak kabul edilmektedir (18). Aynı zamanda anne sütünün içerdiği yağ asit örüntüsü ve lipaz enzimi bebekte yağ sindirimini kolaylaştırmaktadır (6).

Anne sütünün karbonhidrat içeriğinde laktoz önemli bir bileşendir. Laktoz, kalsiyum ve magnezyum minerallerinin emilimini arttırarak kemik gelişimini olumlu yönde etkilemektedir. Galaktoz ile lipidlerin yaptığı bileşimler beyin gelişimi açısından önemli bir etkiye sahiptir. Ayrıca anne sütünde protein ve yağlara bağlı bulunan karbonhidratlar, büyümeyi uyardığından "büyüme faktörü” olarak adlandırılmaktadır (6).

Anne sütünün içeriğindeki vitamin ve minerallerin biyoyararlılığı yüksektir. Yenidoğanlarda K vitaminini sentezleyecek bağırsak florası henüz oluşmadığından bu vitamin yetersiz kalır. D vitamini ihtiyacı ise güneş ışınlarından faydalanarak ya da takviye alınarak sağlanabilmektedir. D ve K vitamini dışında anne sütündeki vitaminler bebeğin gereksinimini karşllayacak miktardadır (18). 
Tablo 2. Anne sütünün anti-infektif bileşenleri ve özellikleri

\begin{tabular}{|c|c|}
\hline Laktoferrin & $\begin{array}{l}\text { Vücutta demirin bağlanmasını sağlayarak zararlı mikroorganizmaların üremesini engelleyen bir } \\
\text { proteindir. Anti-inflamatuvar olmasının yanında büyüme faktörü olarak da tanımlanır (6). }\end{array}$ \\
\hline Kazein & Çeşitli bakteri ve virüslerin vücuttaki mukozalara tutunmasını engellemektedir (19). \\
\hline Bifidus Faktörü & $\begin{array}{l}\text { Bağırsak pH’ını düşürerek diyareye neden olan zararlı mikroorganizma ve mantarların üremesini } \\
\text { engelleyen Laktobasillus bifidus bakterilerinin üremesini sağlamaktadır (19). }\end{array}$ \\
\hline Lizozim & Bakteri öldüren kimyasal maddelerin etkileşimini sağlamaktadır (6). \\
\hline $\begin{array}{l}\text { İnterferon, } \\
\text { Laktoperoksidaz }\end{array}$ & Bakterilerin gelişmesini durduran ve antiviral etkisi olan bir proteindir (19). \\
\hline Müsin & $\begin{array}{l}\text { Mukozal bariyeri koruma, antimikrobiyal aktivite ve immün sistem düzenleyicisi olarak işlev } \\
\text { göstermektedir (20). }\end{array}$ \\
\hline $\begin{array}{l}\text { Komplemanlar, } \\
\text { Fibronektin }\end{array}$ & $\begin{array}{l}\text { C3 opsonin adı verilen antijenle birleşerek fagositozu hassas kılan bir antikor olarak görev almaktadır } \\
\text { (6). }\end{array}$ \\
\hline Sitokinler & $\begin{array}{l}\text { Yenidoğan bağışıklığını geliştirmekte rol almaktadırlar. Kolostrumda daha fazla miktarda bulunur. } \\
\text { Bazıları inflamasyonu arttırken bazıları baskılamaktadır (19). }\end{array}$ \\
\hline Antioksidanlar & Oksijen radikallerini tutarak ve $\mathrm{H}_{2} \mathrm{O}_{2}$ 'yi yıkarak lipid oksidasyonunu önlemektedirler (19). \\
\hline Nükleotidler & $\begin{array}{l}\text { Bağırsağın zarar gören kısımlarını onararak antikor yanıtını arttırmaktadırlar. Bazı anti-infektif } \\
\text { bileşenlerle hareket ederek etkilerini güçlendirmektedirler (19). }\end{array}$ \\
\hline İmmunoglobinler & $\begin{array}{l}\text { Bu grupta başta sekretuvar IgA olmak üzere IgG, IgM, IgD, IgE gibi bağışıklık sağlayan ve antikor olan } \\
\text { immunoglobinler bulunmaktadır. Sekretuvar IgA, meme bezlerinden emzirme ile bebeğe geçerek } \\
\text { bebeği çeşitli bakteri ve virüslerden korumaktadır (6). }\end{array}$ \\
\hline Enzimler & $\begin{array}{l}\text { Özellikle prematüre bebeklerde düşük safra tuzu konsantrasyonlarında bile aktifleşerek yağ sindirimi } \\
\text { ve emilimini sağlayan lipaz, meme bezlerinde süt lipitleri sentezinde rol alan lipoprotein lipaz, laktoz } \\
\text { sentezinde rolü olan galaktozil transferaz anne sütünde bulunarak yarar sağlayan enzimlerdendir (6). }\end{array}$ \\
\hline $\begin{array}{l}\text { Hormonlar ve } \\
\text { Büyüme Faktörleri }\end{array}$ & $\begin{array}{l}\text { Solunum ve gastrointestinal sistemde etki gösteren Epidermal Büyüme Faktörü (EGF), Sinir Büyüme } \\
\text { Faktörü (NGF), İnsülin Benzeri Büyüme Faktörü (ILGF-1) gibi protein yapılı büyüme faktörleri anne } \\
\text { sütünde bulunmaktadır. Büyüme faktörlerinin konsantrasyonu kolostrumda en fazladır. Büyüme } \\
\text { faktörü dışında anne sütünde Gonadotropin Salgılayan Hormon (GNRH), Tirotropin Salgılatıcı Hormon } \\
\text { (TRH), Tiroid Uyarıcı Hormon (TSH), Triiyodotironin (T3), parathormon, kalsitonin, prolaktin, östrojen, } \\
\text { progesteron, kortikosteroidler gibi birçok hormon bulunmaktadır (19). }\end{array}$ \\
\hline $\begin{array}{l}\text { Anne sütü } \\
\text { oligosakkaritleri }\end{array}$ & $\begin{array}{l}\text { Kolosturumda daha yoğun bulunan ve en az } 200 \text { türü bulunan oligosakkarittler, bağırsak mukozal } \\
\text { yüzeyinde immün modülatör aktiviteyi uyarmakta ve sitokin üretimini modüle etmektedir (11). }\end{array}$ \\
\hline
\end{tabular}

Anne sütündeki anti-infektif bileşenler: Anne sütü eşsiz bir besin olarak kabul edilir. Bağışılklık sağlayan maddeler, büyüme ve gelişmeyi etkileyen hormon ve büyüme faktörleri anne sütünü eşsiz kılan özelliklere örnek olarak gösterilebilir (Tablo 2) $(6,19)$.

Anne sütünün enfeksiyonlara karşı koruyucu etkileri: Anne sütünde bulunan müsin, laktoalbumin, laktoferrin, sekretuvar immünglobulin A (sIgA), triptofan ve diğer whey proteinleri ile birlikte kazein proteinleri yenidoğanlarda immün sistemin gelişimini sağlayarak hem bakteriyel hem de viral patojenlere (korona, influenza vb.) karşı koruyuculuk sağlamaktadır (21).
Kazein proteinleri; lenfosit proliferasyonu, $\mathrm{B}$ ve $\mathrm{T}$ hücre aktivasyonu, makrofaj fagositik aktivitesi ve sitokin ekspresyonunun azaltılması yoluyla anti-inflamatuvar etkisi göstererek immünomodülatör peptitler sağlamaktadır (22-24). Kazein fraksiyonlarından kappa kazein, insanlarda kırmızı kan hücrelerinin hemaglütinasyonunu ve influenza virüs enfeksiyonunun inhibisyonunu başlatabilmektedir (25). Benzer şekilde, başka bir kazein fraksiyonu, intravenöz olarak pnömoni tedavisi alan farelerde virüsün gastrik veya mide epitel hücrelerine tutunmasını engellemekte ve Helikobakter pilori enfeksiyonuna karşı mukozal korumayı desteklemektedir $(21,26)$. 
Kolostrumda olgun süte göre daha yüksek oranda bulunan glikoprotein yapıdaki laktaderin (lactadherin); patojen bağlanmasını inhibe ederek, düzenleyici T hücrelerinden İnterlökin 10 (IL-10) ve Dönüştürücü Büyüme Faktörü Beta (TGF-§) salınımını indükleyerek ve ayrıca intestinal dendritik hücre gelişimini destekleyerek semptomatik rotavirüs enfeksiyonunu önleyen membran molekülüdür (20).

Süt proteinlerinden sIgA, toplam süt proteinlerinin \%25’ini ve anne sütünde bulunan antikorların \%90'ını oluşturan baskın bir immünoglobulindir (27). Bu immünoglobulin emzirmeyoluylabebeğeaktarılabilir. sIgA, bağırsak orjinli B hücreleri tarafindan üretilir, lenf ve kan yoluyla meme bezi de dâhil olmak üzere farklı bezlere taşınırlar. Salgılandıktan sonra bez hücrelerinden transsitoz yoluyla lümene geçen sIgA, süt içeriğinin bir parçası haline gelerek solunum yolu ve bağırsak enfeksiyonlara karşı koruyuculuk oluşturur (28). Yenidoğan domuzlarda yapılan bir çalışmada, protein eksikliği olan bir diyet uygulandığında, viral bir ajana yanıt olarak üretilen sIgA miktarının azaldığı görülmüştür. Düşük protein alımı, anjiyotensin dönüştürücü enzim II (ACE2) yoluyla triptofanın düşük emilimine sebep olur, bağışıklık yanıtını bozar, mikrobiyal homeostazın ve bağırsak iltihabının deregülasyonunu indükler. Sonuç olarak emzirmeye ara verilmesi düşük protein alımına neden olarak yenidoğanın gelişimini ve enfeksiyon yanıtını olumsuz yönde etkileyebilir (29).

Anne sütünde bulunan antienfektif bileşenlerden immünglobulin yapıda olmayan müsinlerin intestinal sistemde bariyer görevi görmesi, proteinlerin ve protein yapıda diğer biyoaktif bileşenlerin özellikle immün sistemi düzenlemeleri, bebeğin ilk mikrobiyotasını oluşturmaları ve mikrobiyal homeastazı sağlamaları gibi etkileriyle yenidoğanı birçok enfeksiyondan korudukları bildirilmektedir (30-32). SARS-CoV-2 ile enfekte kişilerin akciğerlerinde intestinal bakterilerin bulunması, bağırsak disbiyosizi ile arasında bağlantı olduğunu (33-35) ve bağırsak mikrobiyotasının homeastazının sağlanmasının önemli olabileceğini düşündürmüştür. Bununla birlikte farklı çalışmalarda, SARS-CoV-2 virüsü ile enfekte annenin sütünden geçen antikorların da bağışıklık sağlayarak yaşamın ilk yılında koruyuculuk sağladığı belirtilmektedir $(36,37)$.

\section{Anne Sütü ile Bulaş Riski}

COVID-19 geçiren annelerin sütünden antikor geçişi görülürken, enfekte annelerin süt analizlerinin yapıldığı çalışmaların çoğunda virüs tespit edilmemiştir (Tablo 3).

Roma'da bir çocuk hastanesinde anne sütünde koronavirüs varlığının araştırıldığı bir vaka çalışmasında, COVID-19 tanısıyla hastaneye gelen iki anneden alınan sağılmış anne sütü örneklerine PCR analizi yapılmış ve virüs tespit edilememiştir. Çalışmanın sonucunda hastanede kalış süresini azaltması ve karantinanın yol açtığı strese faydalı olması açısından emzirmenin desteklenmesi, doğrudan anne sütü alınamadığı durumlarda ise sütün sağılarak bebeğin anne sütünü alması gerekliliği savunulmuştur (38).

Wuhan'da üçüncü basamak sağlık merkezinde yapılan başka bir çalışmada, on iki annenin sütünde COVID-19 nükleik asitine rastlanmamıştır. Buna karşılık doğumdan üç gün sonra üç anneden alınan anne sütü örneklerine yapılan antikor testi sonucunda IgG tipi antikorların belirgin bir şekilde arttığı görülmüştür. $\mathrm{Bu}$ çalışma anne sütünün virüs içermemesinin yanı sıra, antikordaki artış sayesinde yenidoğana bağışıklık sağlaması gibi faydalarını ortaya koymuştur (39).

Almanya'da iki anne ve yenidoğan doğumdan sonra COVID-19 semptomları göstermiş ve testlerinin pozitif çıkması ile hastaneye yatırılmışlardır. Ardından 1013. günde alınan süt örneklerinin PCR analizi bir annede pozitif çıkarken diğer annede sonuç negatif çıkmıştır. Yenidoğanların emzirme yoluyla mı yoksa farklı bir şekilde mi enfekte olduğu bilinmemektedir (40).

Anne sütünün virüs içerip içermediği konusunda yapılan bir diğer çalışmada, Çin'in Hubei eyaletinde on altı enfekte anneden alınan kırk dört anne sütü örneğinin hiçbirinde virüse rastlanmamıştır. 
Tablo 3. Anne sütü ile bulaş riski üzerine yapılan çalışmalar

\begin{tabular}{|c|c|c|c|c|c|c|}
\hline $\begin{array}{l}\text { Araştırmacılar } \\
\text { ve Yıl }\end{array}$ & Yer & Amaç & Türü & Örneklem & Metot & Sonuç \\
\hline $\begin{array}{l}\text { Salvatori et al. } \\
\text { - } 2020 \text { (38) }\end{array}$ & Roma & $\begin{array}{l}\text { Anne sütünde } \\
\text { koronavirüs } \\
\text { varlığı }\end{array}$ & Olgu & 2 anne & Anne sütü analizi & $\begin{array}{l}2 \text { anne sütü numunesi PCR } \\
\text { analizi } \rightarrow \text { Negatif }\end{array}$ \\
\hline $\begin{array}{l}\text { Gao et al. - } \\
2020 \text { (39) }\end{array}$ & Wuhan & $\begin{array}{c}\text { Anne sütünde } \\
\text { koronavirüs } \\
\text { varlığı ve antikor } \\
\text { içeriği }\end{array}$ & $\begin{array}{c}\text { Gözlemsel } \\
\text { analiz }\end{array}$ & 12 anne & Anne sütü analizi & $\begin{array}{l}\text { Koronavirüs nükleik asidi } \\
\text { ve IgG tipi antikorlar tespit } \\
\text { edilmiştir. }\end{array}$ \\
\hline $\begin{array}{l}\text { Groß et al. - } \\
2020(40)\end{array}$ & Almanya & $\begin{array}{l}\text { Anne sütünde } \\
\text { koronavirüs } \\
\text { varlığı }\end{array}$ & Olgu & 2 anne & Anne sütü analizi & $\begin{array}{l}1 \text { anne sütü PCR } \\
\text { analizi } \rightarrow \text { Negatif } \\
1 \text { anne sütü PCR } \\
\text { analizi } \rightarrow \text { Pozitif }\end{array}$ \\
\hline $\begin{array}{l}\text { Peng et al. - } \\
2020 \text { (1) }\end{array}$ & Hubei & $\begin{array}{c}\text { Anne sütünde } \\
\text { koronavirüs } \\
\text { varlığı ve antikor } \\
\text { içeriği }\end{array}$ & Kesitsel & $\begin{array}{l}16 \text { anneden } \\
44 \text { anne } \\
\text { sütü örneği }\end{array}$ & $\begin{array}{l}\text { Onaylanmış, şüpheli } \\
\text { ve kontrol grubu } \\
\text { olmak üzere } 3 \\
\text { grup } \rightarrow \text { Anne sütü } \\
\text { analizi }\end{array}$ & $\begin{array}{c}\text { PCR analizleri } \rightarrow \text { Negatif } \\
\text { Ileri tarihlerde IgM tipi } \\
\text { antikorlar tespit edilmiştir. }\end{array}$ \\
\hline
\end{tabular}

COVID-19 olduğu saptanmış sekiz anneden semptomların başlamasından 3-68 gün sonra toplanan otuz sekiz örnekten yirmi birinin anne sütü numunelerinde IgM antikoru tespit edilmiştir. $\mathrm{Bu}$ da anne sütünün yenidoğan üzerindeki koruyucu etkisini kanıtlamaktadır (1).

\section{Emzirme Sırasında Temas ile Bulaş Riski}

CoviD-19'lu annelerden emzirme sirasinda yenidoğana virüs geçişinin incelendiği çalışmalar Tablo 4'te sunulmuştur.

Koronavirüsün bebek beslenmesi üzerine etkisini incelemek amacıyla Amerika'da üç hastanede yüz altmış anne-yenidoğan çifti üzerinde yapılan bir çalışmada, katılımcılar anne-yenidoğan ayrılmadan asemptomatik ve semptomatik, anne-yenidoğan ayrılarak asemptomatik ve semptomatik olmak üzere dört gruba ayrılmıştır. Emzirme, asemptomatik anneden ayrılmamış grupta en yüksek oranda gözlenmiştir. Ayrılan çiftlerin üzerinde ayrılma sebebi olarak COViD-19'un önemli bir etkisi olduğu görülmüştür. Ayrılmamış, emzirmeye devam eden grupta ise hiçbir bebek enfekte olmamıştır. $\mathrm{Bu}$ hastaneler salgının başında anne-yenidoğan çiftlerinin ayrılması gerektiğini savunan bir kılavuz yayınlamıştır. Daha sonradan emzirmenin gerçekleşmemesi ile bebeğin sağlık durumunda artan olumsuzluklar yüzünden kllavuz revize edilerek asemptomatik annelerin gerekli kişisel koruyucu ekipmanlar kullanarak emzirmeye devam etmesi ve sadece semptomatik annelerin ayrılması gerektiği savunulmuştur (4).

İspanya'da bir hastanede yirmi iki COVID-19'lu anne üzerinde yapılan başka bir çalışmada, yenidoğanda enfeksiyon riskinin belirlenmesi amaçlanmıştır. Yirmi iki anneden yirmisi hastaneye yatarken bebeklerini emzirmeyi tercih etmiştir. Yenidoğanların çoğu sadece anne sütü ile beslenmiş, geri kalanlar ise emzirme sağlanana kadar geçici bir süre tamamlayıcı beslenmeye ihtiyaç duymuştur. Sadece on bir vakada emzirme ve deri teması zamanında yapılmıştır. Gerekli önlemlerin alındığı bu vakalar sonucunda minimum anne-yenidoğan komplikasyonu meydana gelmiş ve hiçbir yenidoğan enfekte olmamıştır (41).

Buna benzer olarak New-York’ta bir hastanede yüz on altı COVID-19'lu anne ve yüz yirmi yenidoğan üzerinde yapılan bir çalışmada, bir ay boyunca emzirmenin güvenilirliğini belirlemek amaçlanmıştır. Yenidoğanların ilk yirmi dört saat içinde yapılan test sonuçları negatif çıkmıştır. Çalışmanın ilerleyen 
zamanlarında bazı olumsuzluklar nedeniyle takibi devam eden yenidoğan sayısı seksen ikiye düşmüştür. Yaşamın ilk 5-7 gününde seksen iki yenidoğanın altmış sekizi annelerinin yanında kalmıştır ve hepsi emzirilmiştir. Yedinci günün sonunda yapılan PCR testleri negatif çıkmıştır. Ardından yaşamlarının ilk on dört gününde emzirmeye devam eden ve takibi tamamlanarak test yapılan yetmiş iki yenidoğanda virüs tespit edilememiştir. Yapılan çalışmanın sonucunda perinatal bulaşmanın söz konusu olmadığı ve annelere eğitim verilerek yeterli koruma sağlandığında emzirmenin güvenli olduğu gösterilmiştir (42).
COVID-19 sebebiyle annelerin emzirme tercihlerinin değişmesi üzerine yapılan diğer bir çalışmada, Çin’in Hubei eyaletinde gebelerin yirmi dördü onaylanmış grup (COVID pozitif), on dokuzu şüpheli grup, yirmibiri ise kontrol grubu (COVID doğrulanmamış) olmak üzere gruplara ayrılmışlardır. Doğumdan sonra altmış dört anneden kırk dördü anne sütünü sağarak bebeklerini beslemeyi tercih etmişlerdir. Onaylanmış gruptaki iki anne ve kontrol grubundaki on üç anne doğumdan sonraki yedi gün içinde doğrudan anne sütü vermeye başlamıştır. Şüpheli gruptaki bebeklerini sağılmış süt ile besleyen annelerden hiçbiri doğumdan sonraki yedi gün içinde doğrudan temas ile emzirmemiştir.

Tablo 4. Emzirme sırasında temas ile bulaş riski üzerine yapılan çalışmalar

\begin{tabular}{|c|c|c|c|c|c|c|}
\hline $\begin{array}{l}\text { Araştırmacılar } \\
\text { ve Yıl }\end{array}$ & Yer & Amaç & Türü & Örneklem & Metot & Sonuç \\
\hline $\begin{array}{l}\text { Popofsky et al. } \\
-2020 \text { (4) }\end{array}$ & New York & $\begin{array}{l}\text { Virüsün emzirme } \\
\text { üzerine etkisi }\end{array}$ & Kesitsel & $\begin{array}{l}160 \text { anne- } \\
\text { yenidoğan }\end{array}$ & $\begin{array}{c}\text { Katılımcılar; } \\
\text { ayrılmamış } \\
\text { asemptomatik, } \\
\text { ayrılmış } \\
\text { asemptomatik, } \\
\text { ayrılmamış } \\
\text { semptomatik, } \\
\text { ayrılmış } \\
\text { semptomatik olmak } \\
\text { üzere } 4 \text { gruba } \\
\text { ayrılmıştır. }\end{array}$ & $\begin{array}{l}\text { Ayrılmamış grupta } \\
\text { bebek enfekte olmadığı } \\
\text { için emzirmeye devam } \\
\text { edilmesi gerektiği } \\
\text { önerilmiştir. }\end{array}$ \\
\hline
\end{tabular}

\begin{tabular}{|c|c|c|c|c|c|c|}
\hline $\begin{array}{l}\text { Pereira et al. - } \\
2020(41)\end{array}$ & Madrid & $\begin{array}{l}\text { Yenidoğanda } \\
\text { enfeksiyon } \\
\text { riskinin } \\
\text { belirlenmesi }\end{array}$ & Retrospektif & $\begin{array}{c}22 \text { anne- } \\
\text { yenidoğan }\end{array}$ & $\begin{array}{l}\text { Hastaneye yatışı olan } \\
\text { ve emzirmeyi tercih } \\
\text { eden } 20 \text { annenin } \\
\text { yenidoğanlarına PCR } \\
\text { testi yapılmıştır. }\end{array}$ & $\begin{array}{l}\text { Önlem alınarak emzirme } \\
\text { sağlandığında yenidoğan } \\
\text { test sonucu negatif } \\
\text { çımıştır. }\end{array}$ \\
\hline $\begin{array}{l}\text { Salvatore et al. } \\
-2020(42)\end{array}$ & New York & $\begin{array}{l}\text { Emzirmede } \\
\text { bulaş riskinin } \\
\text { belirlenmesi }\end{array}$ & $\begin{array}{l}\text { Gözlemsel } \\
\text { kohort }\end{array}$ & $\begin{array}{l}166 \text { anneden } \\
78 \text { 'si, } 106 \\
\text { yenidoğan } \\
\text { 82'si takibi } \\
\text { tamamlamış } \\
\end{array}$ & $\begin{array}{c}\text { Yenidoğanlara } \\
\text { yaşamlarının ilk } 24 \\
\text { saati, 5-7. günü ve } 14 . \\
\text { gününde PCR testi } \\
\text { yapılmıştır. }\end{array}$ & $\begin{array}{l}\text { Emzirmeye devam } \\
\text { eden annelerin takibi } \\
\text { yapıldığında bebekte } \\
\text { virüs tespit edilmemiştir. }\end{array}$ \\
\hline $\begin{array}{l}\text { Peng et al. - } \\
2020 \text { (1) }\end{array}$ & Hubei & $\begin{array}{l}\text { COVID-19 } \\
\text { sebebiyle } \\
\text { annelerin } \\
\text { emzirme } \\
\text { tercihlerinin } \\
\text { değerlendirilmesi }\end{array}$ & Kesitsel & $\begin{array}{l}64 \text { anne } \\
66 \\
\text { yenidoğan }\end{array}$ & $\begin{array}{c}\text { Katılımcılar } \\
\text { pozitif(24), } \\
\text { şüpheli(19) ve } \\
\text { kontrol grubu(21) } \\
\text { olmak üzere } 3 \\
\text { gruba ayrılmış, } \\
7 \text { gün sonunda } \\
\text { yenidoğanlara PCR } \\
\text { testi yapılmıştır. }\end{array}$ & $\begin{array}{l}\text { Düşük emzirme } \\
\text { oranları bebeklerde } \\
\text { sağlık sorunlarına yol } \\
\text { açtığından emzirme } \\
\text { önerilmiştir. }\end{array}$ \\
\hline
\end{tabular}


Tablo 4. Devamı

\begin{tabular}{|c|c|c|c|c|c|c|}
\hline $\begin{array}{l}\text { Araştırmacılar } \\
\text { ve Yıl }\end{array}$ & Yer & Amaç & Türü & Örneklem & Metot & Sonuç \\
\hline $\begin{array}{l}\text { Sharma et al. - } \\
2020(43)\end{array}$ & Hindistan & $\begin{array}{c}\text { Doğumdan } \\
\text { sonra emzirme } \\
\text { temasının riski }\end{array}$ & Olgu & $\begin{array}{c}1 \text { anne- } \\
\text { yenidoğan }\end{array}$ & $\begin{array}{l}\text { Doğum sonrasında } \\
\text { temasa izin verilerek } \\
\text { yenidoğanın } \\
\text { emzirilmesi } \\
\text { sağlanmıştır. }\end{array}$ & $\begin{array}{l}7 \text { gün sonunda bebeğe } \\
\text { test yapılmış, sonuç } \\
\text { negatif çıkmıştır. }\end{array}$ \\
\hline $\begin{array}{l}\text { Gao et al. - } \\
2020 \text { (39) }\end{array}$ & Wuhan & $\begin{array}{l}\text { Anne sütünden } \\
\text { virüs geçişi ve } \\
\text { temas riski }\end{array}$ & Retrospektif & $\begin{array}{c}14 \text { anne- } \\
\text { yenidoğan }\end{array}$ & $\begin{array}{c}\text { Hastalık } \\
\text { başlangıcından } \\
\text { sonra orofaringeal } \\
\text { ve nazofaringeal } \\
\text { sürüntü örnekleri } \\
\text { alınarak anne ve } \\
\text { yenidoğana PCR testi } \\
\text { yapılmıştır. }\end{array}$ & $\begin{array}{c}\text { Anne sütünden bulaş } \\
\text { olmamış ve emzirilen } \\
\text { hiçbir yenidoğan enfekte } \\
\text { olmamıştır. }\end{array}$ \\
\hline
\end{tabular}

Yapılan çalışmanın sonucunda emzirme ile anneden çocuğa bulaşma kanıtı bulunamamıştır (1).

Hindistan'da yapılan bir vaka çalışmasında doğum sonrasında maske kullanımı sağlanarak anne ve yenidoğan arasında temasa izin verilmiş ve emzirme sağlanmıştır. Yedi gün sonra bebeğe test yapılmış ve sonuç negatif çıkmıştır (43).

Bunlara benzer olarak Wuhan'da üçüncü basamak sağllk merkezinde on dört anne-yenidoğan üzerinde yapılan çalışmada on iki annenin önlem alınarak emzirilmesi sağlanmıştır. Çalışma sonucunda hiçbir yenidoğan enfekte olmamıştır. Böylelikle emzirme sırasında bulaş riskinin tedbirler alındığı takdirde azaldığı ve sağladığı birçok fayda açısından emzirmeye devam edilmesi gerektiği savunulmuştur (39).

\section{SONUÇ VE ÖNERILER}

Yapılan çalışmaların sonuçlarına göre her ne kadar salgının başlarında çoğu sağlık otoritesi koronavirüsün temas ve damlacık yoluyla bulaşması nedeni ile bebeğin emzirme sırasında enfekte olacağını düşünerek, anne-yenidoğan çiftinin ayrılması gerektiğini savunsa da gerekli kişisel koruyucu ekipmanlar kullanılarak ve hijyen kurallarına uyularak emzirmenin bir bulaş riski oluşturmadığı, aksine emzirmenin gerçekleşmediği durumlarda hem annenin psikolojisi açısından hem de yenidoğanın anne sütünden yararlanamamasından dolayı çeşitli olumsuzlukların meydana geldiği görülmektedir.

Yapılan birçok çalışma sonucunda enfekte annenin sütünde virüse rastlanılmamıştır. Bazı çalışmalarda bir süre geçtikten sonra yapılan antikor testleri sonucunda, bebeğin bağışıklığını destekleyen antikor seviyeleri yüksek bulunmuştur. Bu sonuçlar doğrultusunda enfekte annenin sütünde virüs bulunmadığı, aksine olumlu bir etki olarak sütün içindeki antikor düzeyleri sayesinde anne sütünün bebeğe bağışıklık sağlayabileceği belirtilmiştir. Sonuç olarak, çalışma sonuçlarında anne sütünün en önemli özelliklerinden biri olan bağışıklık destekleyiciliği ile yenidoğan için ilk aşı kabul edilmesi tekrar vurgulanmıştır. Ancak anne sütünün SARS-CoV-2 virüsü üzerine koruyucu mekanizmalarında görev alan biyoaktif moleküllerin etkinliklerin belirlenebilmesi için deneysel çalışmaların yapılması faydalı olacaktır. Elde edilen çalışmaların sonuçları ve DSÖ’nün rehberi (3) dikkate alındığında, CovíD-19 tanısı alan annelerin koruyucu ekipmanlar kullanarak ve hijyen kurallarına dikkat ederek anne sütü gibi mucizevi bir besinden bebeğin faydalanmasını sağlamaları ve emzirmeyi sürdürmeleri önerilebilir. 
Yazarlık katkısı - Author contributions: Çalışmanın tasarımı: VO, ÇB; İlgili literatürün taranmasl: VO; Makale taslağının oluşturulması: VO, ÇB; Iç̧erik için eleştirel gözden geçirme: VO, ÇB; Yayınlanacak versiyonun son onayl: VO, $C ̧ B$ - Study design: VO, ÇB; Literature review: VÖ; Draft preparation: VO, ÇB; Critical review for content: VO, ÇB; Final approval of the version to be published: VO, ÇB.

Çıkar çatışması - Conflict of interest: Yazarlar çıkar çatışması olmadığını beyan ederler. - The authors declare that they have no conflict of interest.

\section{KAYNAKLAR}

1. Peng S, Zhu H, Yang L, Cao L, Huang X, Dynes M, et al. A study of breastfeeding practices, SARS-CoV-2 and its antibodies in the breast milk of mothers confirmed with COVID-19. Ssrn. 2020;4.

2. Danışma Kurulu B. Genel bilgiler, epidemiyoloji ve tanı. 2020;19.

3. WHO. Breastfeeding and COVID-19. Bull Acad Natl Med. 2020;204(9):e140-1.

4. Popofsky S, Noor A, Leavens-Maurer J, QuintosAlagheband ML, Mock A, Vinci A, et al. Impact of maternal severe acute respiratory syndrome coronavirus 2 detection on breastfeeding due to infant separation at birth. J Pediatr. 2020;226:64-70.

5. Kyle $\mathrm{MH}$, Glassman ME, Khan A, Fernández CR, Hanft E, Emeruwa UN, et al. A review of newborn outcomes during the COVID-19 pandemic. Semin Perinatol. 2020;44(7):151286.

6. Samur G. Anne Sütü. Ankara: T.C. Sağlık Bakanlığ Yayıni; 2008. 1-25 p.

7. Chen H, Guo J, Wang C, Luo F, Yu X, Zhang W, et al. Clinical characteristics and intrauterine vertical transmission potential of COVID-19 infection in nine pregnant women: a retrospective review of medical records. Lancet. 2020;395(10226):809-15.

8. Li Q, Guan X, Wu P, Wang X, Zhou L, Tong Y, et al. Early transmission dynamics in Wuhan, China, of novel coronavirus-infected pneumonia. N Engl J Med. 2020;382(13):1199-207.

9. Wu D, Wu T, Liu Q, Yang Z. The SARS-CoV-2 outbreak: What we know. Int J Infect Dis. 2020;94:44-8.

10. Wu Z, McGoogan JM. Characteristics of and important lessons from the coronavirus disease 2019(COVID-19) outbreak in China. Jama. 2020;323(13):1239-42.
11. Lin C, Ye R, Xia YL. A meta-analysis to evaluate the effectiveness of real-time PCR for diagnosing novel coronavirus infections. Genet Mol Res. 2015;14(4):1563441.

12. Nicholson LB. The immune system. Essays Biochem. 2016;60(3):275-301.

13. Salazar N, Valdés-Varela L, González S, Gueimonde M, de los Reyes-Gavilán CG. Nutrition and the gut microbiome in the elderly. Gut Microbes. 2017;8(2):82-97.

14. Ballard O, Morrow AL. Human milk composition: nutrients and bioactive factors. Pediatr Clin North Am. 2013;60(1):49-74.

15. Rowe-Murray HJ, Fisher JRW. Baby friendly hospital practices: Cesarean section is a persistent barrier to early initiation of breastfeeding. Birth. 2002;29(2):12431.

16. Ahi S, Borlu A, Balci E, Günay O. Mothers’ Breastfeeding initiation in the first hour after birth and related factors at a baby friendly hospital. Ahi Evran Medical Journal. 2019;3(2):41-7.

17. Lonnerdal B, Hernell O. Iron, zinc, copper and selenium status of breast-fed infants and infants fed trace element fortified milk-based infant formula. Acta Paediatr Int J Paediatr. 1994;83(4):367-73.

18. Giray H. Anne sütü ile beslenme. Sürekli Tıp Eğitimi Derg. 2004;1:12-5.

19. Uraş N. Anne sütünün oluşumu ve içeriği. Türk Dünyası Uygul ve Araştırma Merk Yenidoğan Derg. 2017;2(2):130-53.

20. He YY, Lawlor NT, Newburg DS. Human milk components modulate toll-like receptor-mediated inflammation. Adv Nutr. 2016;7(1):102-11.

21. Hernell O, Hansson L. Human milk k-casein and inhibition of helicobacter pylori adhesion to human gastric mucosa. J Pediatr Gastroenterol Nutr. 1995;21(3):288-96.

22. Daddaoua A, Puerta V, Zarzuelo A, Suárez MD, Sánchez De Medina F, Martínez-Augustin O. Bovine glycomacropeptide is anti-inflammatory in rats with hapten-induced colitis. J Nutr. 2005;135(5):1164-70.

23. Kayser H, Meisel H. Stimulation of human peripheral blood lymphocytes by bioactive peptides derived from bovine milk proteins. FEBS Lett. 1996;383(1-2):18-20.

24. Müller-Buschbaum P, Gebhardt R, Roth S V, Metwalli ZE, Doster W. Effect of calcium concentration on the structure of casein micelles in thin films. Biophys J. 2007;93(3):960-8. 
25. Kawasaki $\mathrm{Y}$, Isoda $\mathrm{H}$, Tanimoto $\mathrm{M}$, Dosako $\mathrm{S}$, Idota T, Nakajima I, et al. Inhibition by k-casein glycomacropeptide and lactoferrin of influenza virus hemagglutination. Biosci Biotechnol Biochem. 1993;57(7):1214-5.

26. Parker F, Migliore-Samour D, Floch F, Zerial A, Werner $\mathrm{GH}$, Jollès J, et al. Immunostimulating hexapeptide from human casein: amino acid sequence, synthesis and biological properties. Eur J Biochem. 1984;145(3):67782.

27. Hurley WL, Theil PK. Perspectives on immunoglobulins in colostrum and milk. Nutrients. 2011;3(4):442-74.

28. Telemo E, Hanson LA. Antibodies in milk. J Mammary Gland Biol Neoplasia. 1996;1(3):243-9.

29. Fischer DD, Kandasamy S, Paim FC, Langel SN, Alhamo MA, Shao L, et al. Protein malnutrition alters tryptophan and angiotensin-converting enzyme 2 homeostasis and adaptive immune responses in human rotavirus-infected gnotobiotic pigs with human infant fecal microbiota transplant. Clin Vaccine Immunol. 2017;24(8):e00172-17.

30. Hashimoto T, Perlot T, Rehman A, Trichereau J, Ishiguro $\mathrm{H}$, Paolino M, et al. ACE2 links amino acid malnutrition to microbial ecology and intestinal inflammation. Nature. 2012;487(7408):477-81.

31. Metidji A, Omenetti S, Crotta S, Li Y, Nye E, Ross E, et al. The environmental sensor AHR protects from inflammatory damage by maintaining intestinal stem cell homeostasis and barrier integrity. Immunity. 2018;49(2):353-62.

32. Borges E, Lima P, Peluso A, Sampaio W, Oliveira J, Oliveira M, et al. Angiotensin-(1-7) Influences tryptophan absorption in the rat and mouse intestine. Br J Med Med Res. 2017;19(4):1-9.

33. Dhar D, Mohanty A. Gutmicrobiota and Covid-19-possible link and implications. Virus Res. 2020;285(April):198018.

34. He Y, Wang J, Li F, Shi Y. Main clinical features of COVID-19 and potential prognostic and therapeutic value of the microbiota in SARS-CoV-2 infections. Front Microbiol. 2020;11.
35. He LH, Ren LF, Li JF, Wu YN, Li X, Zhang L. Intestinal flora as a potential strategy to fight SARS-CoV-2 infection. Front Microbiol. 2020;11:1388.

36. Demers-Mathieu V, Do DM, Mathijssen GB, Sela DA, Seppo A, Järvinen KM, et al. Difference in levels of SARSCoV-2 S1 and S2 subunits- and nucleocapsid proteinreactive SIgM/IgM, IgG and SIgA/IgA antibodies in human milk. J Perinatol. 2021;41(4):850-9.

37. Fox A, Marino J, Amanat F, Krammer F, Hahn-Holbrook J, Zolla-Pazner S, et al. Robust and specific secretory IgA against SARS-CoV-2 detected in human milk. iScience. 2020;23(11):101735.

38. Salvatori G, De Rose DU, Concato C, Alario D, Olivini N, Dotta A, et al. Managing COVID-19-positive maternalinfant dyads: An Italian experience. Breastfeed Med. 2020;15(5):347-8.

39. Gao X, Wang S, Zeng W, Chen S, Wu J, Lin X, et al. Clinical and immunologic features among COVID-19affected mother-infant pairs: antibodies to SARS-CoV-2 detected in breast milk. New Microbes New Infect. 2020;37:100752.

40. Groß R, Conzelmann C, Müller JA, Stenger S, Steinhart $\mathrm{K}$, Kirchhoff F, et al. Detection of SARS-CoV-2 in human breastmilk. Lancet. 2020;395(10239):1757-8.

41. Pereira A, Cruz-Melguizo S, Adrien M, Fuentes L, Marin E, Forti A, et al. Breastfeeding mothers with COVID-19 infection: A case series. Int Breastfeed J. 2020;15(1):1-8.

42. Salvatore CM, Han JY, Acker KP, Tiwari P, Jin J, Brandler $\mathrm{M}$, et al. Neonatal management and outcomes during the COVID-19 pandemic: an observation cohort study. Lancet Child Adolesc Heal. 2020;4(10):721-7.

43. Sharma KA, Kumari R, Kachhawa G, Chhabra A, Agarwal R, Sharma A, et al. Management of the first patient with confirmed COVID-19 in pregnancy in India: From guidelines to frontlines. Int J Gynecol Obstet. 2020;150(1):116-8. 